\title{
legelivet
}

På disse sidene i Tidsskriftet - legelivet - finner du stoff om legers liv.

Her er det presentasjon av arbeidssteder, nyhetssaker, nye doktorgrader,

nye spesialister og minneord. Alt samlet på ett sted - så du kan følge enda bedre med.

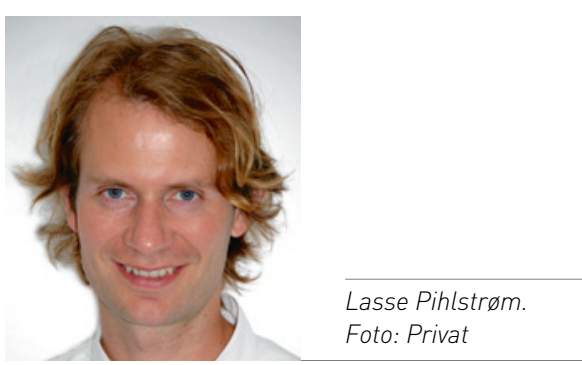

Lasse Pihlstrøm (f. 1980) er stipendiat ved Universitetet i Oslo og lege ved Nevrologisk avdeling, Oslo universitetssykehus.

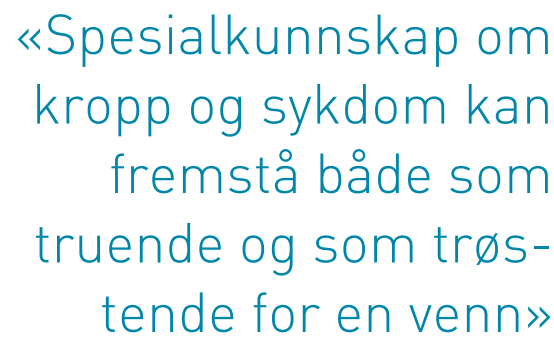

tende for en venn»

\section{Når leger vet for mye}

«Men du som er lege, vet sikkert alt om dette.» Hva svarer man da?

Legen som visste for mye er tittelen på kollega og Ylf-leder Christer Mjåsets første roman. I den er det en ung allmennlege på Hitra som vet for mye. Men kan ikke den tittelen også noen ganger føles som en tautologi - et utsagn som nødvendigvis må være sant? Det finnes i hvert fall sosiale situasjoner der man som lege automatisk havner i en komplisert særstilling på grunn av den kunnskapen som følger med yrket.

Det er jo ikke det at vi leger vet så mye mer enn andre. Langt derifra. Men den kunnskapen vi har, ligger så tett på andre menneskers liv. Folk elsker jo å snakke om helse, kropp og sunnhet, enten sjangeren er tragedie eller komedie. Men den som har en slektning som har født barn, en nabo som har begynt på en ny diett eller en venninne som har ligget på sykehus, endrer fortellerstilen litt med en lege i rommet. «Dette vet jo sikkert du alt om», sier vedkommende kanskje. Ja, man vet jo i hvert fall litt om akkurat dette, men en forelesning vil pense samtalen over i teknisk og upersonlig retning og ødelegge den gode stemningen.

Ofte er ikke slikt helseprat så alvorlig. Da er det kanskje heller ikke så farlig om man som lege velger å forelese litt, fleipe eller bare lytte. Men andre ganger inngår private historier om helse og sykdom som sentrale elementer i menneskers selvbilde.
Da gjelder det å trå varsomt. Vi har alle behov for å finne våre egne tolkninger og forklaringer på det som skjer oss i livet, selv om enkelte historier ikke klinger helt troverdige eller medisinsk korrekte i kritiske legeører.

I klinisk arbeid er det helselovgivningen som gjelder. Legens tolkning av situasjonen må formidles tydelig som grunnlag for informert samtykke. Ibsens doktor Relling er åpenbart ikke på jobb i stykket Gengangere. Med sin berømte advarsel mot å ta livsløgnen fra et gjennomsnittsmenneske står han for en linje der det snarere gjelder å skåne sine medmennesker for ubehagelige sannheter.

I virkeligheten, overfor venner, slektninger og naboer, handler det om å finne en balansegang. Det er ikke alltid lett. Det vil komme sensitive samtaler om helse, og blikkene vil bli rettet mot legen. Kanskje er det et godt utgangspunkt å erkjenne at spesialkunnskap om kropp og sykdom kan fremstå både som truende og som trøstende for en venn. Det kommer an på hvordan vi kommuniserer. «Legen som visste mye» kunne jeg godt tenke meg å være. Men det er like viktig å unngå å bli «vennen som visste for mye».

\section{Lasse Pihlstrøm}

lasse.pihlstrom@gmail.com 